УДК $94(497.5)$ «1990/20...»

DOI: https://doi.org/10.33782/eminak2020.3(31).455

\title{
ОСОБЛИВОСТІ ПРАВОСУДДЯ РЕСПУБЛІКИ ХОРВАТІЯ У СФЕРІ ВІЙСЬКОВИХ ЗЛОЧИНІВ (ЗА МАТЕРІАЛАМИ «МИКЛУШЕВСЬКОГО ПРОЦЕСУ»)
}

\author{
Микола Нагірний \\ Володимир-Волинський педагогічний фаховий коледж імені А.Ю. Кримського \\ (Володимир-Волинський, Україна) \\ e-mail: mykola76@hotmail.com \\ ORCID: https://orcid.org/0000-0002-9319-8540
}

\begin{abstract}
У статті розглянуто переслідування та покарання військових злочинців у Республіці Хорватія за підсумками сербсько-хорватської війни 1990-х років. Описано процес такого переслідування на прикладі матеріалів так званої «миклушевської справи». Висвітлено основні проблеми даного процесу. Виділено його особливості, характер і тривалість. Показано еволюцію даного судового процесу крізь призму зміни поведінки органів правосуддя Хорватії, заходи хорватської влади задля вирішення цих проблем. Проаналізовано долі головних учасників процесу. Встановлено, що "миклушевська справа» виявилась невдалою для тогочасного хорватського правосуддя, показавши його недосконалість. Показано значення цього процесу для сучасної України.
\end{abstract}

Ключові слова: русини, Миклушевці, Сербська Краӥна, терор, етнічні чистки, судовий процес, геноцид, військові злочини проти цивільного населення

Перед сучасною Україною стоїть чимало викликів, пов'язаних із ймовірною реінтеграцією Окупованих районів Донецької та Луганської областей (ОРДЛО) у своє адміністративно-правове поле. Одним з них є питання відповідальності за військові злочини, вчинені на Донбасі з 2014 р. по даний час. Частина суспільства однозначно вимагає суворо покарати військових злочинців, інші - застосувати певні види амністії для пришвидшеної реінтеграції тимчасово окупованих регіонів.

У цьому контексті корисним для України буде досвід Хорватії, яка у 1990-х рр. зіштовхнулася з подібними проблемами.

Шлях Хорватії до незалежності на початку 1990-х рр. був ускладнений сепаратизмом сербів в ії̈ окремих районах ${ }^{1}$. Упродовж 1990-91 рр. вони утворили так звану Республіку Сербська Країна (РСК), яка охоплювала майже третину території Хорватії².

Новопостала сербська квазідержава займала територію, де проживала значна частина несербського населення, у тому числі й нащадки переселенців з українських земель ${ }^{3}$. Зокрема, найбільше їх було в окупованих населених пунктах - місті

\footnotetext{
1 Barić N. Srpska pobuna u Hrvatskoj 1990-1995. Stvaranje hrvatske drzave i Domovinski rat / Zdenko Radelic (et al.). Zagreb, 2006. S. 191-209.

${ }^{2}$ Нагірний М. Становлення та розвиток Республіки Хорватія: державно-політичний аспект. Нововолинськ, 2008. С. 53-55; Република Српска Крајина / уредник 3. Каличанин. Книн-Београд, 1996. C. 417.

3 Živić D. Demografski okvir i gubitci tijekom Domovinskog rata i poraća. Stvaranje hrvatske drzave $i$ Domovinski rat / Zdenko Radelic (et al.). Zagreb, 2006. S. 438.
} 
Вуковар, селах Петровці та Миклушевці (Східна Славонія). Так, у Миклушевцях 3 понад 670 мешканців русинів й українців було, за різними даними, 523-529 осіб4.

Сербська Країна взяла на озброєння принципи «Великої Сербії». Тож несербське населення (у тому числі й русини та українці) опинилися на шляху політики «сербізації» захоплених територій.

У кожному зайнятому повсталими сербами населеному пункті організовувались штаби територіальної оборони (місцеві адміністрації, запроваджені владою т. зв. РСК), причому туди входили і представники нашої діаспори, що симпатизували офіційному Белграду5.

Такого терору, який проводив штаб територіальної оборони у селі, миклушевські русини не зазнавали за всі 150 років свого проживання на цих землях. Руйнування, грабежі, ґвалтування, побиття, пошкодження греко-католицької церкви, жорстокі вбивства окремих родин - це перелік діяльності нової владй.

Русини й українці зазнавали не тільки терору, а й потрапили під «етнічні чистки». Людей виганяли під приводом співпраці з ворогом і за майновим критерієм: у першу чергу заможніших, аби можна було заселити сербів до їхніх осель .

Українські родини, які ще залишились у тих місцевостях (це здебільшого селяни), жили практично у табірних умовах, з обмеженою свободою руху. Над ними постійно знущалися, їх били, позбавляли найнеобхідніших речей і харчів, в агресивній формі примушували залишати свої будинки, щоб їх заселити сербами i, таким чином, штучно змінити національний склад населення регіону8.

Тому русини й українці вітали акції хорватської армії «Блиск» і «Буря», якими вона повернула більшість земель під юрисдикцію Загреба. Контрольовані сербами території Хорватії зменшились уп'ятеро (від 25\% до 5\%). Однак повернення Східної Славонії, де проживало найбільше русинів й українців, передбачалося робити поступово і під контролем УНТАЕС (Перехідної адміністрації ООН)ำ.

Мирна реінтеграція Подунав'я, що відбувалася під міжнародним контролем і 3 урахуванням європейських стандартів прав людини та свобод національних меншин, стала найважливішим кроком хорватського керівництва, який призвів до закінчення сербсько-хорватської війни.

Під тиском міжнародних структур Хорватія взяла на себе чимало зобов'язань у сфері забезпечення прав національних меншин, зокрема, сербів. Велике невдоволення сербської сторони спровокували хорватські списки сербів, підозрюваних у військових злочинах. Однак у процесі мирної реінтеграції ці списки неодноразово коригувалися у бік зменшення, що викликало обурення вже у хорватської громад-

\footnotetext{
4 Такач Г. Миклошевска воєна хронология (1). Нова думка. 1991. № 90/91. С. 11; Biki Đ. Rusini Mikluševaca u Domovinskom ratu 1991. Mikluševci, 2001. S. 11; Burda S. Iz rada Kriznog staba Saveza 1991-1993 g. (1). Нова думка. 1998. № 105. C. 41; Wertheimer-Baletić A. Jedno i pol stoljeće u brojčanom razvoju stanovništva Vukovara i vukovarskoga kraja. Društvena istraživanja. 1993. № 4-5 / God. 2 (1993). Br. 2-3. Ožujak-lipanj 1993. S. 467.

5 Такач Г. Миклошевска воєна хронология (3). Нова думка. 1992. № 94/95. С. 10; Biki Đ. Rusini Mikluševaca... S. 65.

6 Такач Г. Миклошевска воєна хронология (3)... С. 11-12.

7 Пушце нас най жиєме. Нова думка. 1992. № 94/95. С. 23.

8 Нагірний М. Хорватські русини та українці: суспільство, ідентичність, культура наприкінці XX століття. Нововолинськ: «Видавнича група «Формат», 2012. С. 89.

9 Нагірний М. Становлення та розвиток Республіки Хорватія... С. 62.
} 
ськості ${ }^{10}$, оскільки жертвам довелося співіснувати з фактично військовими злочинцями, які їх піддавали тортурам чи виганяли.

Хорватсько-сербській війні 1990-х рр. і питанню реінтеграції Східної Славонії під юрисдикцію офіційного Загреба присвячено величезний масив літератури. Варто хоча б згадати у праці Н.Барича 11 , А.Холєвац-Тукович12, Д.Живича 13 , Р. Якешевич14 та інших. Однак наукових розвідок щодо військових злочинів проти русинсько-українського населення та відповідних судових процесів з цього приводу майже немає. Окремі дотичні роботи носять більше загальний (Д.Живич15), теоретичний (I.Йосіповіч16) або публіцистичний (Г. Такач17, М.Киш ${ }^{18}$, Дж. Бикий ${ }^{19}$ ) характер. Тож спираючись, насамперед, на матеріали судових справ, заповнимо цю прогалину.

Мета даної роботи - розглянути події окремого судового процесу над звинуваченими у військових злочинах на території Хорватії (так звана «миклушевська справа»). Мета зумовила такі завдання: проаналізувати особливості цього процесу, показати його суперечності та вичленити основні уроки і висновки, які може взяти з нього Україна.

Промовистим прикладом покарання військових злочинців $є$ так званий «миклушевський процес». Для української громадськості він цікавий, насамперед, тим, що стосується злочинів проти русинсько-української громади села Миклушевці у Східній Славонії. Слід зазначити, що сучасне законодавство Хорватії розмежовує ці дві етнічні групи. І хоча автор стоїть на позиції русинсько-української єдності (русини - це історична назва українців та їхня сучасна етнографічна група зі своїми унікальними особливостями), надалі у статті вживатиметься етнонім «русини» відповідно до самоідентифікації місцевих мешканців села.

Однією з найвідоміших судових справ у Республіці Хорватія була «Миклушевська група» або «Злочин у Миклушевцях», спрямована проти тих, хто навесні 1992 р. депортував 98 і вбив чотирьох осіб із цього русинсько-українського села20.

\footnotetext{
${ }^{10}$ Barić N. Srpska oblast Istočna Slavonija, Baranja i Zapadni Srijem - od «Oluje» do dovršetka mirne reintegracije hrvatskog Podunavlja (drugi dio). Scrinia Slavonica: Godišnjak Podružnice za povijest Slavonije, Srijema i Baranje Hrvatskog instituta za povijest. 2012. №12 (1). S. 344-353.

${ }^{11}$ Barić N. Srpska oblast Istočna Slavonija, Baranja i Zapadni Srijem - od «Oluje» do dovršetka mirne reintegracije hrvatskog Podunavlja (prvi dio). Scrinia Slavonica: Godišnjak Podružnice za povijest Slavonije, Srijema i Baranje Hrvatskog instituta za povijest. 2011. № 11 (1). S. 393-454; Barić N. Srpska oblast Istočna Slavonija... (drugi dio). S. 323-370.

12 Holjevac Tuković A. Proces mirne reintegracije Hrvatskog Podunavlja. Zagreb: Despot infinitus, 2015. $336 \mathrm{~s}$.

13 Živić D. Mirna reintegracija hrvatskog Podunavlja, 1996-2016. Političke analize. 2016. № 7 (25). S. 3-8.

${ }^{14}$ Jakešević R. Mirovne misije Ujedinjenih nacija i rješavanje etničkih sukoba: studija slučaja Istočne Slavonije. Politička misao : časopis za politologiju. 2012. № 49 (2). S. 186-203.

15 Živić D. Demografski okvir... S. 420-483.

16 Josipović I. Praćenje suđenja za ratne zločine: izvještaj za 2007. / uredile K. Kruhonja i V. Kastratović. Osijek: Centar za mir, nenasilje i ljudska prava, 2007.123 s.

17 Такач Г. Миклошевска воєна хронология (1)... С. 11; Такач Г. Петровци спадли медзи остатнїма (1). Нова думка. 1992. № 92/93. C. 24-27; Takać G. Stradanja Rusina i Ukrajinaca Republike Hrvatske u Domovinskom ratu. Нова думка. 1994. № 100. С. 14-20.

18 Kiš M. Republika Hrvatska i hrvatski Rusini i Ukrajinci i danas se bore protiv fašizma. Rusini i Ukrajinci u Republici Hrvatskoj (1991-1995) / urednik S. Burda. Zagreb, 1995. S. 15-19.

${ }_{19}$ Biki Đ. Rusini Mikluševaca...

20 Varga B. Tragedija Ukrajinaca i Rusina iz Vukovara. Aljazeera Balkans: веб-сайт. URL: http://balkans.aljazeera.net/vijesti/tragedija-ukrajinaca-i-rusina-iz-vukovara
} 
«Миклушевську справу» хорватська влада розглядала як один із великих судових процесів у сфері військових злочинів, який поряд із судовими розглядами справ про військові злочини у Гаазі щодо країн колишньої Югославії мав показати хорошу репутацію хорватської судової влади під час інтеграції країни в $\mathrm{CC}^{21}$.

Суд у Вуковарі очікувався як наймасовіший судовий процес щодо військових злочинів у Дунайському регіоні 22 .

Розслідування розпочалося ще 19 січня 1993 р., у той час, коли Миклушевці та значна частина Вуковарсько-Сріємської жупанії перебували під контролем сербських сепаратистів та були недоступні для судових і поліційних органів Республіки Хорватія, а велика кількість свідків і жертв перебувала у вигнанні по всій Хорватії чи на окупованій території 23 . Це ускладнило та сповільнило процес.

Державна прокуратура Осієцької жупанії подала обвинувальний акт № КТ37/93 від 29 квітня 1996 р. проти 35 осіб за звинуваченням їх у вчиненні кримінального злочину геноциду, ст. 119. ОКЗ (Osnovni krivični zakon - головний кримінальний кодекс Республіки Хорватія, далі - ОКЗ РХ) проти русинів та інших несербів у селі Міклушевці поблизу Вуковару з кінця 1991 року до середини 1992 p. ${ }^{24}$ Характерно, що третину серед підозрюваних становили русини - мешканці Миклушевців. Тож виходило так, що суд звинувачував членів русинської національності у злочині геноциду проти русинів ${ }^{25}$.

Підсудних звинувачували у навмисному знищенні певної етнічної групи, вбивстві членів групи, заподіянні тяжких тілесних ушкоджень і насильницькому переміщенні населення; таким чином вони вчинили злочини проти людства та злочини проти міжнародного права - геноцид 26.

Обвинувачені, як члени штабу територіальної оборони, запровадили комендантську годину для всіх несербів, видали спеціальні перепустки для пересування по селу та поза ним, таким чином повністю завадили вільному переміщенню місцевих жителів. 18 травня 1992 р. обвинувачені брали участь у вигнанні жителів Миклушевців, переважно русинів та інших несербів, змусивши їх підписувати заяви про добровільний виїзд із села з переписуванням свого майна так званій владі Сербської Країни ${ }^{27}$. Усі убиті жертви були русинами: Юліан Голик, Вероніка Голик, Михайло Голик і Славко Гайдук 28.

У час, коли було винесено обвинувальний акт, усі обвинувачені були недоступні судовим органам Республіки Хорватія (частина перебувала у Східній Славонії, реінтеграція якої завершилася на початку 1998 р., частина виїхала до Сербії), і їх не

\footnotetext{
21 Varga B. Tragedija Ukrajinaca i Rusina...

22 Ponovo odložen proces za zločin u Mikluševcima. Radio Slobodna Europa: веб-сайт. URL: https://www.slobodnaevropa.org/a/822916.html

${ }^{23}$ Zločin u Mikluševcima. Documenta. Centar za suočavanje $s$ prošlošću: веб-сайт. URL: https://www.documenta.hr/hr/zločin-u-mikluševcima.html

24 Ponovo odložen proces za zločin u Mikluševcima...; Optužnica ŽDO u Osijeku od 29. travnja 1996. Documenta. Centar za suočavanje $s$ prošlošću: веб-сайт. URL: https://www.documenta.hr/assets/files/Sudjenja/optuznica_ZDO_iz_Osijeka_od_29._travnja_1996..pdf 25 Varga B. Tragedija Ukrajinaca i Rusina...

26 Zločin u Mikluševcima. Teте: веб-сайт. URL: https://www.dw.com/hr/zločin-u-mikluševcima/a2346940

27 Centar za mir, nenasilje i ljudska prava, 18.03.2015, zločin u Mikluševcima, okr. Mirko Ždinjak. Documentaciono informacioni centar Veritas: веб-сайт. URL: http://www.veritas.org.rs/centar-za-mirnenasilje-i-ljudska-prava-18-03-2015-zlocin-u-miklusevcima-okr-mirko-zdinjak/

28 Zločin u Mikluševcima. Documenta...
} 
могли допитати. Тому жупанський (окружний) суд Осієка 21 лютого 1997 р. вирішив, що обвинувачених судитимуть заочно 29.

Навіть після реінтеграції Східної Славонії кількість фактично присутніх підозрюваних була мізерною. Спочатку на слуханнях у Вуковарі були присутні 10 обвинувачених: по 5 сербів і русинів. А 31 травня 2004 р. один із підозрюваних (серб Йован Ціцо) самовільно залишив місце проживання та виїхав до Сербії

Поступово кількість обвинувачених зменшувалася - через смерті підозрюваних або брак доказів.

Так, судовими рішеннями від березня 2003 р. та квітня 2004 р. було припинено провадження щодо восьми померлих обвинувачених. Загалом упродовж слідства померло 13 обвинувачених, і щодо них усіх слідство було припинено.

Лише протягом 2008-2009 рр. прокуратура відмовилася від подальшого кримінального переслідування стосовно 8 обвинувачених (переважно сербів) через відсутність доказів.

Останнє виправдання щодо двох осіб мало місце 5 лютого 2009 р. Тож на той час підозрюваними залишалося лише 14 осіб (із 35-ти на початку провадження) ${ }^{31}$.

Ті ж підозрювані, котрі залишалися, на судових засіданнях категорично відкидали звинувачення та заявляли, що не вважають себе винними у вчиненні кримінальних злочинів, про які йдеться в обвинувальному акті 32 .

Упродовж процесу суд неодноразово (у 1997 і 2005 рр.) звільняв підсудних зпід варти, наказуючи вжити запобіжних заходів, що забороняють їм залишати місце проживання, зобов'язавши звітувати кожен другий місяць і тимчасово конфіскувавши документи для перетину державного кордону.

Такі дії щодо підсудних були незрозумілими для потерпілих, а також для широкої громадськості, оскільки це був гучний судовий процес за найтяжче кримінальне правопорушення, щодо якого обвинувачених доцільно було б утримувати під вартою під час провадженняз3.

Деякі свідки під час основного слухання були вислухані п'ять і більше разів, що свідчило про те, що слідство було проведене погано, і довелося провести додаткове розслідування.

Загалом тривалість кримінального провадження призводила до відчуття марності та безперспективності процесу. Увага громадськості та ЗМІ за ходом судового процесу теж поступово згасала, незважаючи на те, що це був суд за звинуваченням у геноциді ${ }^{34}$.

Обвинувальний акт було кілька разів змінено й уточнено на підставі показань свідків. Так, коли справу передали від прокуратури Осієка прокуратурі Вуковара, вона внесла зміни в обвинувальний акт, пояснивши це суттєво зміненими обставинами, зібраними доказами та часом вчинення певних інкримінованих діянь. Було змінено фактичний та юридичний опис, а також юридичну кваліфікацію правопорушень. Тож 20 березня 2007 р. підсудних звинуватили у вчиненні військових

\footnotetext{
29 Ibidem.

30 Ibidem.

31 Ibidem.

32 Ibidem.

33 Ibidem.

34 Ibidem.
} 
злочинів проти цивільного населення, зазначених у пункті 1 статті 120 ОКЗ РХ35.

Незабаром, 13 квітня 2007 р., обвинувальний акт знову було змінено відповідно до ст. 119 ОКЗ РХ («геноцид»); однак дії, за які звинувачували підозрюваних, залишалися такими ж, як і в обвинувальному акті від 20 березня 2007 р. («військові злочини проти цивільного населення»), тоді як юридична кваліфікація правопорушення була змінена на початкові звинувачення - «геноцид» 36.

Загалом докази свідчили, що про геноцид не йшлося. Стаття II Конвенції про запобігання та покарання злочину геноциду говорить: «...геноцид - це будь-яке 3 наступних діянь, вчинене з наміром знищити повністю або частково національну, етнічну, расову чи релігійну групу...»³7.

Винуватцями геноциду, як правило, є люди найвищого рангу у військовій та/або політичній ієрархії ${ }^{38}$. Рішення про вчинення діяння повинно бути свідомим, діяти у напрямку знищення цієї групи. У конкретному випадку обвинуваченими $є$ члени сербської та русинської національних меншин, а жертвами - переважно русини й інші несерби. Підсудними були члени штабу місцевої територіальної оборони. Зважаючи на ці факти, у даному конкретному випадку можна говорити про військовий злочин проти цивільних осіб (ст. 120), а не про геноцид (ст. 119) ${ }^{39}$. Зауважимо, що військовий злочин проти цивільних осіб порівняно 3 обвинуваченням у геноциді є менш тяжким злочином.

Загалом від початку порушення справи обвинувальний акт було змінено вісім разів $^{40}$.

Вирок у справі було оголошено 5 лютого 2009 р. Того дня суд у Вуковарі визнав винними у вчиненні військових злочинів 12 осіб (по шість сербів і русинів) та засудив їх до позбавлення волі терміном від 4 до 15 років. Причому середній термін для сербів становив 7,2 років, для русинів - 6,7 років. Максимальні терміни отримали двоє - серб Йован Ціцо та русин Петро Ленджер.

Під час оголошення вироку були присутні підсудні Йоаким Бучко, Зденко Магоч і Дарко Гудак - лише етнічні русини. Інші обвинувачені перебували у розшуку, оскільки вони втекли переважно до сусідньої Сербії та були недоступні для судових органів Хорватії ${ }^{41}$. Вийшло так, що за військовий злочин проти русинів фактично було засуджено лише русинів.

Засідання Апеляційної ради Верховного Суду Республіки Хорватія відбулося 17 листопада 2009 р. Цей суд повністю підтримав рішення суду першої інстанції42.

Новий поштовх справа отримала після екстрадиції з Франції одного з головних підозрюваних - русина Мірко Ждиняка. Він був екстрадований на підставі європейського ордеру, оскільки був заочно засуджений 5 лютого 2009 р. Після його ек-

35 Izmjenjena optužnica od 20. ozujka 2007. godine. Documenta. Centar za suočavanje s prošlošću: вебсайт.

URL:

https://www.documenta.hr/assets/files/Sudjenja/Izmjenjena_optuznica_od_20._ozujka_2007..pdf

36 Izmjenjena optužnica od 13. travnja 2007. godine. Documenta. Centar za suočavanje s prošlošću: веб-

сайт.

URL:

https://www.documenta.hr/assets/files/Sudjenja/Izmjena_optuznice_od_13._travnja_2007..pdf

37 Zločin u Mikluševcima. Documenta...

${ }^{38}$ Josipović I. Praćenje suđenja za ratne zločine...

39 Zločin u Mikluševcima. Documenta...

40 Ibidem.

41 Ibidem.

42 Ibidem. 
страдиції до Республіки Хорватія слід було відновити кримінальне провадження проти підсудного ${ }^{43}$.

Зазначимо, що за вироком від 2009 р. М. Ждиняк отримав 6 років, а за новим провадженням у суді округу Осієк (слухання розпочалися 2 березня 2015 р.) йому дали 5 років ${ }^{44}$. Верховний суд Республіки Хорватія погодився 3 правильністю вироку, але зменшив термін покарання до чотирьох років позбавлення волі 45 .

Таким чином, здобуття Хорватією незалежності на початку 1990-х рр. було ускладнене виявом сепаратистських настроїв серед місцевого сербського населення, підтриманого офіційним Белградом, і втратою значної частини територій. Після реінтеграції Східної Славонії до адміністративно-правового поля Хорватії перед цією державою постала низка завдань, одне з яких - адекватне покарання військових злочинців.

Військові злочини мали місце і на землях компактного проживання русинськоукраїнської діаспори у Хорватії, зокрема, у селі Миклушевці. Сербська Країна взяла на озброєння принципи «Великої Сербії», тож несербське населення опинилися на шляху політики «сербізації» захоплених територій. В умовах сербської окупації миклушевські русини зазнавали терору й потрапили під «етнічні чистки». Їх виганяли, а ті, хто залишились, жили практично у табірних умовах. Тільки з поверненням хорватської влади злочини припинилися.

Так званий «миклушевський процес» мав стати свідченням демократичності судової системи Хорватії, яка на той час прагнула до євроінтеграції, однак фактично із самого початку він наштовхнувся на низку перепон і труднощів. Серед них: відсутність більшості підозрюваних, які втекли до Сербії, затягування розслідування, часті зміни обвинувального акту, виправдання підозрюваних через їхню смерть або відсутність доказів. Даний процес показав недосконалість тогочасної судової системи Хорватії, насамперед у механізмах і нюансах покарання військових злочинців, відповідності покарання масштабам скоєних злочинів. Процес, за яким винуватців мали притягнути за геноцид, у результаті призвів до того, що за злочин геноциду проти русинського населення Хорватії судили представників тієї ж русинської спільноти.

Хорватський досвід у покаранні військових злочинців, хай і не завжди вдалий, 3 огляду на нинішню ситуацію та ймовірну реінтеграцію ОРДЛО в адміністративно-правове поле України, мав би стати важливим уроком для української влади та суспільства.

\section{REFERENCES}

Baric, N. (2011). Srpska oblast Istočna Slavonija, Baranja i Zapadni Srijem - od «Oluje» do dovršetka mirne reintegracije hrvatskog Podunavlja (prvi dio) [The Serb district of Eastern Slavonia, Baranja and Western Syrmia - from the Croatian operation «Storm» to the completion of the peaceful reintegration of the Croatian Danube region (Part one)]. Scrinia Slavonica: Godišnjak Podružnice za povijest Slavonije, Srijema i Baranje Hrvatskog instituta za povijest - Scrinia Slavonica: Yearly Branch for the History of Slavonia, Srijem and Baranja of the Croatian Institute for History, 11 (1), 393-454 [in Croatian].

Baric, N. (2012). Srpska oblast Istočna Slavonija, Baranja i Zapadni Srijem - od «Oluje» do dovršetka mirne reintegracije hrvatskog Podunavlja (drugi dio) [The Serb district of Eastern Slavonia, Baranja and Western Syrmia - from the Croatian operation «Storm» to the completion of the peaceful

\footnotetext{
43 Centar za mir, nenasilje i ljudska prava...

44 Zločin u Mikluševcima. Documenta...

45 Centar za mir, nenasilje i ljudska prava...
} 
reintegration of the Croatian Danube region (Part two)]. Scrinia Slavonica: Godišnjak Podružnice za povijest Slavonije, Srijema i Baranje Hrvatskog instituta za povijest - Scrinia Slavonica: Yearly Branch for the History of Slavonia, Srijem and Baranja of the Croatian Institute for History, 12 (1), 323-370 [in Croatian].

Baric, N. (2006). Srpska pobuna u Hrvatskoj 1990.-1995. [Serbian uprising in Croatia in 1990-1995]. In Zdenko Radelic (Ed.). Stvaranje hrvatske drzave i Domovinski rat - The creation of the Croatian state and the Homeland War. Zagreb, 191-289 [in Croatian].

Biki, D. (2001). Rusini Mikluševaca u Domovinskom ratu 1991 [The Ruthenians of Mikluševtsi in the Homeland War 1991]. Mikluševci [in Croatian].

Burda, S. (1998). Iz rada Kriznog staba Saveza 1991.-1993. g. (1) [From the work of the Crisis Staff of the Alliance in 1991-1993s (1)]. Nova dumka - New opinion, 105, 38-41 [in Croatian].

Holjevac Tukovic, A. (2015). Proces mirne reintegracije Hrvatskog Podunavlja [The process of peaceful reintegration of the Croatian Danube region]. Zagreb: Despot infinitus [in Croatian].

Jakesevic, R. (2012). Mirovne misije Ujedinjenih nacija i rješavanje etničkih sukoba: studija slučaja Istočne Slavonije [UN Peacekeeping missions and the solving of interethnic conflicts: case study of Eastern Slavonia]. Politička misao: časopis za politologiju - Political Thought: A Journal of Political Science, 49 (2), 186-203 [in Croatian].

Josipovic, I. (2007). Praćenje suđenja za ratne zločine: izvještaj za 2007 [War Crimes Trial Monitoring: 2007 Report]. Osijek: Centar za mir, nenasilje i ljudska prava [in Croatian].

Kalichanin, Z. (Ed.) (1996). Republika Srpska Krajina [Republic of Serbian Krajina]. Knin-Beograd [in Serbian].

Kis, M. (1995). Republika Hrvatska i hrvatski Rusini i Ukrajinci i danas se bore protiv fašizma [The Republic of Croatia and Croatian Ruthenians and Ukrainians are still fighting against fascism]. In Burda S. (Ed.). Rusini i Ukrajinci u Republici Hrvatskoj (1991-1995). Zagreb, 15-19 [in Croatian].

Nahirnyi, M. (2008). Stanovlennia ta rozvytok Respubliky Khorvatiia: derzhavno-politychnyi aspekt [The formation and development of the Republic of Croatia: state and political aspect]. Novovolynsk [in Ukrainian].

Nahirnyi, M. (2012). Khorvatski rusyny ta ukraintsi: suspilstvo, identychnist, kultura naprykintsi XX stolittia [Croatian Ruthenians and Ukrainians: society, identity, culture in the late twentieth century]. Novovolynsk: «Vydavnycha ghrupa «Format» [in Ukrainian].

Pushce nas naj zhyjeme [Let us live] (1992). Nova dumka - New opinion, 94/95, 23 [in Ruthenian].

Radio Slobodna Evropa (2004, June 1). Ponovo odložen proces za zločin u Mikluševcima [The trial for the crime in Mikluševci has been postponed again]. Retrieved from https://www.slobodnaevropa.org/a/822916.html [in Croatian].

Takach, G. (1991). Mykloshevska vojena khronologhyja (1) [Miklushevtsi's military chronology (1)]. Nova dumka - New opinion, 90/91, 11 [in Ruthenian].

Takach, G. (1992). Mykloshevska vojena khronologhyja (3) [Miklushevtsi's military chronology (3)]. Nova dumka - New opinion, 94/95, 9-12 [in Ruthenian].

Takach, G. (1992). Petrovtsi spadly medzy ostatnjima (1) [Petrovtsi fell among the last (1)]. Nova dumka - New opinion, 92/93, 24-27 [in Ruthenian].

Takac, G. (1994). Stradanja Rusina i Ukrajinaca Republike Hrvatske u Domovinskom ratu [Sufferings of the Ruthenians and the Ukrainians of the Republic of Croatia in the Homeland War]. Nova dumkaNew opinion, 100, 14-20 [in Croatian].

Varga, B. Tragedija Ukrajinaca $i$ Rusina iz Vukovara [Tragedy of Ukrainians and Ruthenians from Vukovar]. Retrieved from http://balkans.aljazeera.net/vijesti/tragedija-ukrajinaca-i-rusina-izvukovara [in Croatian].

Wertheimer-Baletic, A. (1993). Jedno i pol stoljeće u brojčanom razvoju stanovništva Vukovara i vukovarskoga kraja [One and a half centuries in the numerical development of the population of Vukovar and the Vukovar region]. Društvena istraživanja, 4-5 / God. 2, Br. 2-3, Ožujak-lipanj, 455-478 [in Croatian].

Zivic, D. (2006). Demografski okvir i gubitci tijekom Domovinskog rata i poraća [Demographic framework and losses during the Homeland War and postwar period]. In Zdenko Radelic (Ed.). Stvaranje hrvatske drzave i Domovinski rat - The creation of the Croatian state and the Homeland War. Zagreb, 420-483 [in Croatian].

Zivic, D. (2016). Mirna reintegracija hrvatskog Podunavlja, 1996.-2016 [Peaceful reintegration of the Croatian Danube region, 1996-2016]. Političke analize - Political analysis, 7 (25), 3-8 [in Croatian].

Ždinjak, Mirko (2015, March 18). Centar za mir, nenasilje i ljudska prava, , zločin u Mikluševcima, okr. Mirko Ždinjak [Center for Peace, Nonviolence and Human Rights, crime in Mikluševci]. Retrieved 
from http://www.veritas.org.rs/centar-za-mir-nenasilje-i-ljudska-prava-18-03-2015-zlocin-umiklusevcima-okr-mirko-zdinjak/ [in Croatian].

\section{Mykola Nahirnyi}

(Volodymyr-Volynsky Pedagogical Vocational College named after A.Yu. Krymsky, VolodymyrVolynsky, Ukraine) e-mail: mykola76@hotmail.com

ORCID: https://orcid.org/0000-0002-9319-8540

\section{Peculiarities of the Republic of Croatia Justice in the Field of War Crimes (on the Mate- rials of 'Myklushevtsi Case')}

The prosecution and punishment of war criminals in the Republic of Croatia after Serbia and Croatia war of the 1990s are studied in the paper.

The process of such persecution is described on the materials of the so-called 'Myklushevtsi case' (Mikluševaca). This choice is caused by two factors: firstly, the case had to be the most high-profile in the region; and, secondly, it concerned the representatives of RuthenianUkrainian diaspora in Croatia. The main problems of the process are highlighted. In particular, most of the suspects were hiding in neighboring Serbia, so they were outside the Croatian judiciary. The evolution of this trial is shown through the prism of changes in the behavior of the Croatian judicial bodies (in particular, changes in the indictment, articles of the criminal code, etc.), and the measures taken by Croatian authorities to solve these issues.

The fates of the main participants of the trial, the national composition of both the accused at the beginning of the court hearings, and the actually convicted persons are analyzed. It has been established that the 'Myklushevtsi case' was unsuccessful for the contemporary Croatian judiciary, showing its imperfection. After all, the initial task of the prosecutor's office was to accuse Serbs of genocide against the Ruthenian population. It has been found out that genocide was no longer mentioned in the final court decisions. Instead, the members of the same Ruthenian national minority were convicted of war crimes against the Ruthenian civilian population. Therefore, in general, the process disappointed the initial expectations placed on it by the Croatian authorities.

The significance of this process is shown for modern Ukraine as well, which also does not give up hopes to return certain areas of Donetsk and Luhansk Regions to its administrative and legal field. And, if these plans are implemented, Ukraine will face similar challenges which Croatia had after the reintegration of Eastern Slavonia in the late 1990s.

Keywords: Ruthenians, Myklushevtsi, Serbian Krajina, terror, ethnic cleansing, trial, genocide, war crimes against civilians 